\title{
Evaluation of the Distribution of Direct Cash Assistance (BLT) for the Covid 19 Pandemic Period and the Communication Patterns of the Task Force (Covid 19) in Simpang Keuramat District, North Aceh
}

\author{
Harinawati ${ }^{1, *}$, Risna Dewi ${ }^{2}$, Ratri Candrasari ${ }^{1}$, Jumadil Saputra ${ }^{3}$, Yusri Ibrahin ${ }^{4}$, \\ Zikri Muhammad ${ }^{3}$
}

${ }^{1}$ Communication Science Department, Universitas Malikussaleh, Aceh, Indonesia

${ }^{2}$ Public Administration Department, Universitas Malikussaleh, Aceh, Indonesia

${ }^{3}$ Faculty of Business, Economics, and Social Development, Universiti Malaysia Terengganu, Malaysia

${ }^{4}$ Center for Foundation and Continuing Eductaion, Universiti Malaysia Terengganu

*Corresponding author.Email: harinawati@unimal.ac.id

\begin{abstract}
Evaluation of the distribution of Direct Cash Assistance (BLT) during the Covid 19 Pandemic and the Communication Patterns of the Task Force (Covid 19 Task Force) through the Covid 19 Response Village in North Aceh, especially the Simpang Keuramat sub-district using a case study approach. This study aims to evaluate the Covid-19 Pandemic Direct Cash Assistance Program sourced from the Village Fund. A study of the theory of policy evaluation, BLT distribution and the Communication Patterns of the Task Force (task force Covid 19) at the Covid-19 response village village level, the results of the research on data collection on prospective recipients of direct cash assistance (BLT) were carried out by a team of village volunteers against Covid -19 and conducted a Village Deliberation Specifically (Musdesus) to determine the list of Direct Cash Assistance Recipients (BLT) for Family Beneficiaries (KPM), Evaluation of Direct Cash Assistance Distribution (BLT) in Simpang Keuramat District in 16 Villages will be disbursed for period 1 in April, May, June; period 2 starting July, August, September. The amount of BLT Funds in period 1 (Rp. 600,000) for period 2 and 3 is Rp. 300,000 for period 3 in October, November and December period 3 have not been distributed because the coverage report on the previous Preode response has not been completed. Communication patterns of the Task Force through the Covid Response Village at the village level, through the Star communication pattern, each member communicates and coordinates between volunteers and the District Government and Related Parties. Conclusion Evaluation of the Distribution of Direct Cash Assistance for Simpang Keuramat District has been carried out for periods 1 and 2 but has not yet carried out the distribution of direct cash assistance (BLT) for period 3 because it is waiting for the accountability report to be completed. The communication pattern of the Covid -19 Task Force (Satgas) is starred because Village volunteers against Covid-19 coordinate with all related parties.
\end{abstract}

Keywords: Evaluation, Distribution, Direct Cash Assistance (BLT), Communication Patterns, Covid 19 Response Villages, Keuramat Simpang Keuramat

\section{INTRODUCTION}

Covid - 19 brings a change in the direction of the Indonesian Government's policy, with the issuance of Government regulation Number 12 of 2020 concerning the determination of Non-Natural Disasters for the Spread of Corona Virus Disease 19 (Covid -19) [1] making derivative regulations that follow from the central to the regions, this it becomes interesting to study from the point of view of policy evaluation. 
According to Indiahono (2009: 145) [2] Policy evaluation is assessing the success / failure of policies based on predetermined indicators. To evaluate policy usually refers to two aspects. Namely 1 . Process aspect, indicating that whether during program implementation, all policy guidelines are consistently carried out by the implementers in the field. 2. Outcome aspect shows whether the implemented policies have achieved the predetermined results (output and outcomes).

According to Abidin (2004: 36) [3] Complete evaluation can be divided into 3 types, namely 1 . Initial evaluation. from the policy formulation process to the time before implementing it. 2. Evaluation in the process of implementation or monitoring. 3. Final evaluation, which is carried out after the completion of the Policy implementation process.

According to Widjaja (2000: 102-103) [4] communication patterns are divided into four models, namely: 1) Wheel Communication Patterns Wheel communication patterns are communication patterns from one person to many people; 2) Chain Communication Patterns Chain communication patterns from one person (A) to B to C, to D and so on; 3) Circle Communication Patterns Communication patterns form a circle because communication communication that occurs from A to B, continues to $\mathrm{C}, \mathrm{D}, \mathrm{E}$ and Back to A communication that occurs like a cycle forming a circle; 4) Star Communication Pattern Star Communication Pattern all members communicate with each other. In this study, there are two focus studies, namely the evaluation of the Covid-19 Pandemic Direct Cash Distribution (BLT) and the Covid-19 Task Force Communication Patterns (Covid-19 Response Village).

The Covid 19 pandemic brought changes to government policies in social safety nets, with the issuance of Government Regulation No. 12 of 2020 concerning the determination of Non-Natural Disasters for the Spread of Corona Virus Disease 19 (Covid 19) as a National disaster [1] and making changes to the policy of Permendesa No. 6 of 2020 regarding amendments to Permendesa No. 11 of 2020 concerning priorities for the use of Village Funds in 2020 [5], circular letter of the Minister of Village PDTT No. 8 concerning Villages against Covid 19 [6] and No. 11 of 2020 concerning affirmation of Cash Intensive Work [7], Permendesa No. 16 year 2019 concerning Village Deliberations [8], letter of the Minister of Village PDTT No 1261 / PRI.00 / IV / 2020 concerning Notifications [9], letter of the Director General of PPMD of the Ministry of Village PDTT No. 9 / PRI.00IV / 2020 regarding the instructions for Data Collection of Prospective BLT Fund Recipient Families Village [10].

The policy at the central level was welcomed by the Aceh Regional Government by issuing Aceh Governor's Letter No 1405323 dated March 23, 2020 [11] Decree of the North Aceh Regent No.360 / 184/2020 dated
March 18, 2020 concerning the determination of the status of certain conditions for disease outbreaks due to the Covid virus 19 in Aceh Utara District [12]. North Aceh Regency in handling Covid 19 by issuing Letter No. 41425/613 regarding the Prevention of the Spread of the Corona Virus (Covid 19) through the Village Fund [13] the letter was addressed to the Head of Subdistrict in North Aceh Regency to form Village Volunteers Against Covid -19 by establishing a Village Response to Covid - 19 at the Gampong (village) level throughout North Aceh Regency.

The formation of the Covid-19 Alert Gampong, to help prevent and spread the Corona virus by forming village volunteers against Covid-19 at the Village level (gampong) chaired by Geuchik, the chairman of Tuha Peut Gampong as a representative and members of village officials, members of tuha Peut gampong, hamlet heads, Village local assistants, Hope Family Assistants, Healthy Village Assistants, other assistants who live in Gampong, Gampong Midwives, religious leaders, traditional leaders, community leaders, youth organizations, PKK, Village Community Pengerak cadres (KPMD).

Special Village Deliberations are deliberations carried out according to the needs of the Village community and urgent events (Permendesa No 16/2020 paragraph 1 article 9) [8] as an effort to prevent and overcome the impact of the spread of Covid -19 through the Gampong (village) level, Special Village Deliberations ( incendental) related to changes in the 2020 RKP / APBDES participants consisting of the village government, the Community Empowerment Agency (BPD) and community elements, namely traditional leaders, religious leaders, community leaders, educational figures, farmer group representatives, fishermen group representatives, craftsman group representatives, representatives women's groups, representatives of child care and protection, representatives of poor community groups.

The stages of implementing village deliberations consist of Pre Musrembangdes by coordinating with the local government regarding covid -19 , changes to the RKP related to covid -19 , forming a team of village volunteers against covid -19 , covid volunteers collecting data on potential recipients of BLT Village funds in 2020, reviewing RKP and APBDes 2020 and adjusted to the needs of COVID-19 handlers.

The results of the research are the intersection of the keuramat with an area of $78.78 \mathrm{~km} 2$ / $7978 \mathrm{Ha}$ located 250 above sea level, in the north it is bordered by Kuta Makmur District, in the south it is bordered by Bener Meriah Regency, in the west it is bordered by Lhokseumawe City and in the east it is bordered by Syamtalira Bayu District and Geurodong Pase District, Simpang Keuramat consists of 16 Villages with 16 Village heads and Village secretaries, 50 Hamlet heads 
and 112 Tuha Peut with a total of 10083 people in 2019 (BPS, Simpang Keuramat in Figures 2019) [14]

Simpang Keuramat as one of the sub-districts in North Aceh Regency, in the process of collecting data on prospective recipients of Direct Cash Assistance (BLT), is carried out by village volunteers against Covid -19 consisting of the Gampong Government with a maximum number of 15 members consisting of village heads / Geuchik as chairman and the head of Tuha Peut as deputy chairman consisting of Gampong apparatuses, members of tuha peut Gampong, head of the village local assistant hamlet, assistant to the Family Hope Program $(\mathrm{PKH})$ conducts preliminary data collection to determine potential recipients of direct cash assistance (BLT) at the village level, then the results of data collection at deliberation through the Special Village Deliberation (Musdesus)

Incidental Special Village Deliberations consisting of the Village Government, the Village Consultative Body (BPD) and community elements facilitated by the Village government to discuss the recapitulation of data collection results for Covid 19 Volunteers at the Special Village Deliberative Meeting. Implementation of the Special Village Deliberation after opening the opening remarks of the chairman of the Village Consultative Body (BPD) conveyed the aims and objectives of implementing the Special Village Deliberation, Submitting the head of the Covid - 19 Volunteer team regarding the use of Village Funds for Direct Cash Assistance (BLT), reports on village situations and conditions regarding Covid 19, criteria, data collection mechanism and final results of Village Fund BLT recipient candidates.

Incidental Special Village Deliberations consisting of the Village Government, the Village Consultative Body (BPD) and community elements facilitated by the Village government to discuss the recapitulation of data collection results for Covid 19 Volunteers at the Special Village Deliberative Meeting. Implementation of the Special Village Deliberation after opening the opening remarks of the chairman of the Village Consultative Body (BPD) conveyed the aims and objectives of implementing the Special Village Deliberation, Submitting the head of the Covid - 19 Volunteer team regarding the use of Village Funds for Direct Cash Assistance (BLT), reports on village situations and conditions regarding Covid 19, criteria, data collection mechanism and final results of Village Fund BLT recipient candidates.

The data collection mechanism was carried out by the Covid-19 Village Volunteer team in the Simpang Keuramat sub-district, the team took notes after receiving a letter of assignment from the head of the Covid Covid 19 Volunteer Village (Geuchik / village head) recording starting from the hamlet by registering poor families without the Hope Family Program ( $\mathrm{PKH}$ ) or Non-Cash Food Assistance (BPNT), BLT recipients are also not allowed to be Civil Servants (PNS), TNI / Polri, BUMN and Gampong officials, the Volunteer Team operates in 50 hamlets from 16 villages, paying attention to the data collection component consisting of names, addresses , Account No, Family Hope Program (PKH), Non-Cash Food Assistance (BPNT), Preemployment Card, Loss of livelihood (do not have sufficient economic reserves to survive in the next three months (April 2020), are not recorded but have the right receive the benefits of a Social Safety Net (JPS), family members have chronic / chronic diseases, based on this data collection Village Volunteers Against Covid -19 made limited information ap families that have been recorded in the Qualifying (MS) and Unqualified (TMS) categories of this activity are reported to the Head of Village Volunteers Against Covid - 19.

\section{DISCUSSION}

The Village Fund Direct Cash Transfer (BLT) method uses the following formula: 1) Villages that receive Village Funds of less than IDR 800,000,000 (Eight hundred million Rupiah) allocate a BLT-Village Fund a maximum of $25 \%$ of the total Village funds; 2) Villages receiving Village Funds of Rp. 800,000,000 Rp. 1,200,000,000 (one billion two hundred million rupiah) allocate BLT-Village funds a maximum of $30 \%$ of the total Village Funds; 3) Villages Receiving Village Funds More than IDR 1,200,000,000 (One Billion Two Hundred Thousand Rupiah) Allocate BLT-Village Funds up to $35 \%$ of the total Village Funds; 4) Specifically for Villages where the number of poor families is greater than the allocated budget, they can increase the allocation of funds after obtaining approval from the Regency / City Government.

The period of distribution of BLT - Village Funds is 3 (three) since April 2020 and the amount of Direct Cash Assistance (BLT) funds is IDR 600,000 (six hundred thousand rupiah). As of April, May, June Village Fund Direct Cash Assistance is given to poor families who are not in the Family Hope Program (PKH) and Non-Cash Food Assistance as an effort to create a social safety net for people who come from poor families with criteria that are eligible for assistance can last for three months during the Covid -19 period, the Village Fund Direct Cash Assistance (BLT) program was divided into three periods, namely, the first period in April, May June with a BLT amount of IDR 600,000 (six hundred thousand rupiah), then period two in July, August, September with an amount of IDR 300,000 (Three hundred thousand Rupiah) and a period of three In October, November and December IDR 300,000 (Three Hundred Thousand Rupiah) if assistance during the emergency response period of the first three months in April, May June the amount of assistance received is IDR 600,000 rupiah, this is mandatory to spend through 
the Village Fund, but for periods two and three the amount distributed is IDR 300,000 (three hundred thousand Rupiah) this also depends on the availability of village funds (Village capability).

Village Fund Direct Cash Assistance (BLT) for Simpang Keuramat sub-district, North Aceh Regency, as follows: First period in April, May, June 2020, each village distributed direct cash assistance for village funds as follows (Village) 1) Keude Simpang Empat 216 Beneficiary Families (KPM) Rp. 129,000,000; 2) Seuneubok Punti 48 Beneficiary Families of IDR 28,800,000; 3) Paya Leupah 80 Beneficiary Families (KPM) IDR 48,000,000; 4) Paya Teungoh 56 Beneficiary Families (KPM) IDR 33,600,000; 5) Keubon Baroh 31 Beneficiary Families (KPM) IDR 18,600,000; 6) Meunasah Teungoh 31 Beneficiary Families (KPM) IDR 18,600,000; 7) Meunasah Baroh 36 Beneficiary Families (KPM) IDR 21,600,000; 8) Mancang 23 Beneficiary families (KPM) IDR 13,800,000; 9) Alue Bade 6 Beneficiary Families (KPM) IDR 3,600,000; 10) Meunasah Dayah SPK 89 beneficiary families (KPM) Rp. 53,400,000; 11) Kilometer VI 22 beneficiary families (KPM) Rp. 13,200,000; 12) Kilometer VIII 68 Beneficiary families (KPM) IDR 40,800,000; 13) EI Tarek I 46 Beneficiary Families (KPM) IDR 27,600,000; 14) Ie Tarek II 24 Beneficiary Families (KPM) IDR 14,400,000; 15) Pase Sentosa 53 Beneficiary Families (KPM) IDR 31,800,000; 16) Blang Raleue 58 Beneficiary Families (KPM) IDR 34,800,000. (Realization of the number of recipients of Direct Cash Assistance (BLT) in Simpang Keuramat District, North Aceh Regency in 2020)

Evaluation of the distribution of Direct Cash Assistance (BLT) for Village Funds during the Covid19 Pandemic is the first process of data collection, the difficulty of sorting out middle-class family heads if the poor are clearly measured through houses, wealth and jobs, poor people who have an impact on Covid, this is of course during the Covid -19 period, everyone had the right to apply as part of being affected by Covid so that the Covid-19 Volunteer Team which was tasked with conducting initial data collection at the Hamlet level became Boomerang; Secondly, administrative readiness, it was found that the prospective recipient of direct cash assistance (BLT) was eligible to receive assistance but did not have a name on the Family Card, Hitching Family Card, did not have an KTP, making it difficult for the Volunteer team to enter into the list of Prospective Beneficiary Families (KPM); Third, the amount of direct cash assistance (BLT) from the source of Village Funds is limited according to the percentage of the amount of Village Funds so that the amount is small when it is sorted out; the fourth is the courage of the village apparatus (Covid Volunteer Team -19) to speculate, when the data is obtained, it is not immediately announced, but it is deposited for several weeks while waiting if there are complaints, or there is wrong data to be corrected; Fifth, Disbursement of Direct Cash Assistance (BLT) from Village funds has been given in the form of cash in the first period because the situation during the Covid -19 Pandemic was an emergency, far from the reach of the Bank, as well as laymen so that the first stage was given Direct Cash Assistance (BLT) cash, while for disbursement of period 2 Direct Cash Assistance, through a bank account. Beneficiary Families (KPM) make a Bank Book in the district capital, district capital or Lhokseumawe City, the book creation process must go through government banks such as BRI, BNI, Bank Aceh through assistance by Village / District Facilitators. For the third period of disbursement in October, November, December it has not been carried out because the Accountability Report has not been made so that the third period of direct cash assistance cannot be disbursed.

The Communication Pattern of the Covid-19 Task Force at the Gampong level is a Village Volunteer Team against Covid -19 which was formed based on Village Minister Regulation (PDTT) No.6 of 2020 concerning amendments to Village Ministerial Regulation (PDTT) No.11 of 2019 concerning the use of Village funds one of which is for the prevention and handling of Corona Virus Diseases 2019 (Covid - 19) this regulation is being followed up to the North Aceh Regency level with the issuance of a Regent's Letter dated March 27, 2020 concerning Prevention of the Spread of the Corona Virus (Covid - 19) through Village funds and the establishment of Covid posts in each village through Covid response villages by forming Village Volunteers against Covid - 19 in North Aceh Regency.

Village Volunteer Structure Consists of a Geuchik (Village head) chairman of Tuha Peut as a representative and members consisting of Gampong apparatus, Tuha Peut members, Hamlet Heads, Village Local Assistants, Family Hope Program Assistants (PKH), Healthy Village Assistants, gampong, village midwife, religious leaders, traditional leaders, community leaders from the youth organization, PKK cadres for community activists. The Village Volunteer Team Against Covid carried out the following activities, first to educate about Covid - 19 to explain the symptoms, transmission and how to prevent the spread of Covid - 19 either directly to the community or through Foster and Covid - 19 Prevention banners. interconnect between one volunteer and other volunteers as well as with the community.

Collecting data on residents / communities who are prone to illness, identifying village facilities that can be used as isolation rooms for Covid-19 sufferers, spraying disinfectants in residents' homes, providing hand washing liquid in public places by providing hand washing facilities, providing medical devices for Early detection, protection and prevention of Covid -19 , 
provides information related to the handling of Covid 19 , both in the form of a referral hospital telephone number for Covid-19 handling, an ambulance telephone number that can be contacted during an emergency.

In addition, Village Volunteers Against Covid -19 carried out early detection of the spread of Covid -19 through data collection on community movements in the form of recording guests who entered the village, recording people who left the village who went to other places, recording people who had just come from outside the area (rantau) who had working in big cities, monitoring the development of People Under Monitoring (ODP) and Patients Under Monitoring (PDP) Covid - 19. Ensure that no activities of residents crowd or gather such as wedding meetings, recitation, entertainment that invite the masses.

The communication pattern of the Village Volunteer Team against Covid - 19 occurs in a starry manner, the volunteer team is related to coordinating with Covid 19 handlers at the village level by collaborating with a referral hospital or puskesmas if suddenly there are people who need medical hands immediately the Gampong volunteer team contact the Center Public Health (Puskesmas) or referral hospital. The Covid-19 Volunteer Team provides isolation space in village facilities that allows use and asks residents who have just come from outside the area to carry out independent isolation for 14 days to break the chain of Covid-19 spread. The Volunteer Team also prepares logistics for residents who carry out independent isolation , contacting medical officers or the Regional Disaster Management Agency (BPBD) for follow-up for residents who enter isolation rooms. The Village volunteer team against Covid - 19 always coordinates with the North Aceh Regency government The Village volunteer team against Covid - 19 always coordinates with the North Aceh Regency government through the Health Service and or the Community Empowerment Service, Population Control and Family Planning in the North Aceh district

\section{CONCLUSION}

Evaluation of the Distribution of Direct Cash Assistance (BLT) during the Covid 19 Pandemic is the process of distributing Direct Cash Assistance in the first period of cash with an amount of Rp. 600,000 to beneficiary families in 16 villages in Simpang Keuramat District, the second period of direct cash assistance (BLT ) are distributed through the beneficiary family's account (KPM) with a nominal value of IDR 300,000 in 16 villages in the Simpang Keuramat sub-district. Meanwhile, the distribution of direct cash assistance (BLT) for period three has not been carried out because it is waiting for the second phase of accountability report to be completed so that the third period of direct cash assistance (BLT) has not been distributed.
The communication pattern of Village Volunteers Against Covid - 19 is the Star Communication Pila because the volunteer team is in touch with fellow members, and coordinates with related parties including in the data collection process for non-recipient recipients of the Family of Hope Program (PKH) Village volunteer team against Covid - 19 coordinated with the government of North Aceh Regency through the related Dinas.

\section{REFERENCES}

Abidin, Said Zainal, 2002, Public Policy. Jakarta: Pacur Siwal Foundation.

Indiahono, Dwiyanto, 2009, Public Policy Based on Dynamic Policy

H. A. Widjaja, 2000, Introduction to Communication Studies, Jakarta: Rineka Cipta

Government Regulation Number 12 of 2020 concerning Determination of Non-Natural Disasters for the Spread of Corona Virus Disease 19 (Covid - 19).

Village Ministry Regulation Number 6 of 2020 concerning Amendments to Village Ministry Regulation No 11 of 2020 concerning Priority for the Use of Village Funds.

PDTT Village Minister Circular Number 81 concerning Villages Against Covid - 19

Village Ministerial Regulation (Permendesa) Number 16 of 2019 concerning Village Deliberations.

Village Minister's Letter (PDTT) Number 1261 / PRI.01 / IV / 2020 regarding Notification.

Letter of the Director General of PDMD Kemendes PDTT Number 9 / PRI.00IV / 2020 concerning Guidelines for Data Collection of Prospective Village Fund BLT Recipient Families

Governor of Aceh Letter Number 1405323 dated March 23,2020

Decree of the Regent of North Aceh Number 360/184/2020 dated March 18, 2020 concerning the Determination of the Status of a Certain Situation of Disease Outbreaks due to the Covid 19 Virus in North Aceh Regency

Circular number 41425/613 regarding the Prevention of the Spread of the Corona Virus (Covid 19) through the Village Fund

Central Bureau of Statistics (BPS) Intersection of Keuramat in Figures in 2019. 